\title{
Standard Regulation of Corporate Management
}

\author{
Bushuyev A.N. \\ Gugelev A.V. \\ Yashin N. S. \\ Saratov social and economic institute, Saratov, 410003, Russia
}

\section{Doi:10.5901/mjss.2014.v5n24p442}

\begin{abstract}
Management of corporation through its standard regulation, in comparison with the standard national system of standardization, is more expedient as there is an opportunity to establish corporate rules of development and application of the standards taking into account structure and specifics of industrial corporation and/or area of its activity taking into account interests of all interested parties, including regional interests. For creation of own system of standardization in corporation it is necessary to analyse kinds of activity, to establish, what are expedient for regulating by means of standardization, and then to define head enterprise of industrial corporation which will perform organizational and methodical management of works on corporate standardization.
\end{abstract}

Keywords: corporation, management, system, standardization, standard documentation, formation, standards of the organization of industrial corporation.

\section{Introduction}

Developing QMS strategy at industrial corporations includes setting goals as well as choosing an algorithm for implementing basic corporate standards. According to the authors, it is best to use both the ISO 9001 and 9004 standards, consistent implementation of the provisions of these standards leads to active involvement of all other standards included in the ISO 9000: configuration management (ISO 10007), measuring systems (ISO 10012), project management (ISO 10006), management documentation (ISO / TR 10013), management of the economics of quality (ISO I TR 10014), training (ISO 10015), audit (ISO 19011). The main condition for the successful strategy of the implementation of corporate standards is active and direct participation of the top manager of the corporation. Standards of industrial corporation management (SICM) can and should establish the procedure for developing corporate standards independently, that is, corporations can take a well-documented decision and issue an approval of appropriate organizational and administrative documents on the use and recognition of the legitimacy of the previous and currently existing corporate standards [1]. At the same time the decision should be taken about step-by-step or immediate replacement of all corporate standards and / or changes in their titles. The current Russian GOST ISO 9001-2011 (section 4.2) states explicitly that this documentation can be kept in any form.

Strategy of formation of SMK on industrial corporations, along with statement of the purposes, includes also a choice of option of algorithm of implementation of basic corporate standards. According to authors, simultaneous use thus of the ISO 9001 and 9004 international standards is the best, the coordinated implementation of provisions of these standards causes the necessity of active use of all other standards included in ISO family of a series 9000: on management of a configuration (ISO 10007), on systems of measurement (ISO 10012), on management of the project (ISO 10006), on documents in the field of management (ISO/TO 10013), on management of economy of quality (ISO/TO 10014), on training (ISO 10015), on audit (ISO 19011). The main condition of development of strategy of introduction of corporate standards that it has to pass with direct participation of the first head of corporation. The Standards of the Organization of Industrial Corporation (SOIC) can and have to establish an order of development of the standards independently, that is they can make documentary issued established decision through preparation and the approval of the relevant organizational and administrative document on application and recognition of legitimacy developed earlier and at the moment the existing corporate standards [1]. The question of expediency of stage-by-stage or simultaneous renewal of all corporate standards and/or changes of their designation has to be at the same time resolved. In acting in Russia GOST ISO 9001 - 2011 (item 4.2) it is said directly that this documentation can be in any form [7]. 


\section{Method}

SOPK have to be directed on creation of conditions of mutual interest of all participants of cooperation, both internal, and external, in increase of productivity and efficiency both own production economic activity, and economic efficiency of a production activity of industrial corporation. This approach to creation of system of standard regulation for corporations rather fully meets the requirements of technical regulation in the Russian Federation, is constructed on the principles of TQM and considers specifics of the knowledge-intensive production [5].

The general structure of standards of the enterprise of industrial corporation is given in fig. 1.

Fig. 1. General structure of standards of management of industrial corporation.

THE GENERAL

Basic concepts and dictionary ISO 9000:2008 -

HUNDRED PSK 9000 of the Requirement

Guidelines on SMK assessment

ISO 19011:2008

SOPK 9011
STANDARD

ISO 9001:2008

SOPK 9001

Part I. General requirements

Part II. Special requirements
METHODICAL

Recommendations about activity improvement ISO 9004:2009

$+$

SOPK 9004

Part I.

Part II.

Part VI.

SICM goals are:

- ensuring compliance of corporate products, operation and services;

- improving production;

- using and disseminating the results of research and development in various corporate fields.

However SICM should also contribute to the general goal of standardization:

- ensuring the safety of life and health of citizens, protection of property of natural or legal persons, public or municipal property, environmental protection, protection of life or health of animals and plants;

- ensuring the safety facilities under standardization;

- improving the competitiveness of products, works and services;

- promoting compliance with the requirements of technical regulations;

- contributing to scientific and technical progress;

- securing information compatibility;

- rational use of all corporate resources;

- comparability of the assessments and test results, including economic and statistical data of corporations.

Obviously, in any corporate structure we can identify tasks that can be appropriately addressed through standardization. Current GOST 1.1-2002 "Interstate system for standardization.Terms and definitions" states that "standardization is an activity aimed at achieving the optimum degree of order in a certain area by establishing provisions for common and repeated use in the existing or potential problems." Moreover, that activity is manifested in the development and implementation of standards [2].

The advantage of corporate standardization over nationwide standardization for industrial corporations is their ability to set clear rules for corporate development and application of own standards based on the structure, operation and specificity of its activities.

Naturally, there are other types of documents that can solve the same problem as the standards: various technological and organizational directives, norms, rules, regulations, guidance documents, test procedures, recommendations, etc. General rules for the templates, layout and titles of certain documents, such as technological documentation, are traditionally set at the national level, and as these standards often form part of a set of standards, they are characterized by excessive complexity of the content and structure, and moreover, they are designed for traditional highly specialized enterprises in high-tech industries. It should be noted that the document forms, specified in these standards, are outdated and most modern enterprises keep and submit such documentation in electronic form.

In order to create your own system of standardization it is necessary to systematize corporate activities, identify those types of repeatable operations which should be managed with the help of standardization as well as designate the parent company orstructural unit which will carry out organizational and methodological work on corporate governance standardization. 
The next step in the SICM establishment will be the development of a set of fundamental standards which are designed to establish the following rules:

- how to develop, update and cancel the SICM;

- how to establish, designate and register SICM;

- how to use the existing national standards of the Russian Federation in the SICM;

- how to organize and monitor the compliance with the rules established in the SICM;

- how to create and catalogue a compendium of corporate standards, including information on using the documents included in this compendium [3].

The SICM compendium should include a standard for terms and definitions, which should specify the applicable terms and definitions with regard to corporate structure, as well as establish consistent interpretations of terms and definitions used in standardization of corporate activities.

\section{Results}

Overall goals of organizing corporate standardization should be laid out in a separate SICM, where it is important to specify the goals and principles of standardization for the corporation, to identify individual challenges, to determine the scheduling methodology for corporate standardization, and to define the functions of individual companies. Since documenting the QMS requires more attention, it is necessary to take a closer look at the contents of the fundamental corporate standards.

The most important is the content of the SICM establishing the rules for approving corporate standards. Itis advisable to determine what information should be used in the development of the SICM. According to the authors, the development of the SICM should take into account:

- suggestions from the structural units of industrial corporations that will use these standards;

- results of project, research and development work in the corporation;

- existingnational standards of the Russian Federation;

- international standards;

- experience of leading enterprises in this sector of economy and other information about the latest scientific and technological achievements;

- organizational and administrative documents of federal executive bodies.

At the same time we should not forget that when using documents protected by patents or copyright law we should comply with the rules of the Civil Code of the Russian Federation, and all the necessary information should be presented in the preface to the SICM.

Then it is recommended to appoint a manager responsible for the development and updating of the SICM.

When establishing and regulating the procedure of the SICM development,it is recommended to use the sequence of the following four stages:

- organizing the SICMdevelopment;

- drafting the SICM (first edition) and discussion among all interested parties in the corporation;

- $\quad$ finalizing the SICM project, its adjustment, compliance assessment and examination;

- approval of the SICM, its registration, introduction and dissemination.

The section about the organizational issues of the development and realization of the SICM should coordinate the organizational process with corporate planning documents, including plans for writing corporate standardization programs. The authorsdeem it necessary to establish the possibility of developing the SICM based on organizational and administrative documents of the corporate plan.

When establishing the procedure for the development of the draft version of the SICM it is advisable to compile an explanatory note, which formulates requirements for its content and design. Also it is advisable to prepare a mailing list for the draft version of the SICM to be sent for consideration in various departments. Timeframe should be established for interested parties to consider the draft standard and form an opinion.

Next a procedure for considering and discussing feedback to the draft standard should be established by the developer, and a procedure for finalizing the SICM. Additionally, it is expedient to analyze summaries of the feedback and opinions.

The next step in the corporate standardization planning should address the procedure for reviewing the final version of the SICM and its approval by all corporate structures. It is necessary to set the dates for the procedure, and everyone should be notified that after the deadline the SICM cannot be adjusted in any way. While discussing the SICM, health and safety, environmental and property issues should be considered. Those issues must be approved by the state 
control and supervision authorities that regulate these questions in accordance with the legislation of the Russian Federation.

The development of the SICM can be greatly simplified by the systematization of corporate regulatory documents which enables establishing a corporate management system based not only on the results of external influence but also the transformation of the existing management systems of all companies merged into a corporation.

Table 1 presents an exemplary list of the SICM on corporate governance, the development of which would improve the quality of corporate governance.

Table №1. A list of SICM

\begin{tabular}{|c|c|}
\hline Standards of Industrial Corporate Management. & Main sections of the document \\
\hline Management system. Basic issues & $\begin{array}{l}\text { Structure of Management System in corporation } \\
\text { Structure of the target subsystem } \\
\text { Structure of the functional subsystem } \\
\text { Structure of support subsystem } \\
\text { Structure of outer management system } \\
\text { Structure of management subsystem }\end{array}$ \\
\hline $\begin{array}{l}\text { Management system. } \\
\text { Management of product development cycles }\end{array}$ & $\begin{array}{l}\text { Structure of product life cycle in corporation } \\
\text { Methods of predicting the production cycles of products } \\
\text { Methods of predicting the profitability of production cycles } \\
\text { Information and forecasting support }\end{array}$ \\
\hline Management system. Principles of corporate management & $\begin{array}{l}\text { The point of the system approach } \\
\text { Principles of corporate management }\end{array}$ \\
\hline Management system.General management methods & $\begin{array}{l}\text { Administrative methods of corporate management } \\
\text { Socio-psychological methods of corporate management } \\
\text { Economic methods of corporate management }\end{array}$ \\
\hline $\begin{array}{l}\text { Management system. Economic grounds to improve the efficiency } \\
\text { of corporate management }\end{array}$ & $\begin{array}{l}\text { Principles of corporate management feasibility } \\
\text { Economic grounds to improve organizational and technical level of production } \\
\text { Economic grounds to improve the competitiveness of corporation } \\
\text { Information support of measurement of corporate management effectiveness }\end{array}$ \\
\hline $\begin{array}{l}\text { Management system. Methodical support of product } \\
\text { competitiveness }\end{array}$ & $\begin{array}{l}\text { Measuring of product competitiveness } \\
\text { Methods of studying factors of corporate competitive advantage } \\
\text { Information support of corporate management }\end{array}$ \\
\hline $\begin{array}{l}\text { Management system. Marketing and corporate market strategy } \\
\text { build-up }\end{array}$ & $\begin{array}{l}\text { Concept of corporate marketing } \\
\text { Functions of corporate marketing } \\
\text { Building-up of standards of product competitiveness } \\
\text { Building-uptechnique of corporate market strategy } \\
\text { Information support of corporate management }\end{array}$ \\
\hline Management system. Corporate pricing policy & $\begin{array}{l}\text { Principles of corporate pricing } \\
\text { Methods for price prediction }\end{array}$ \\
\hline Management system. Quality control & \begin{tabular}{|l} 
System of corporate quality indicators \\
Certification of products \\
Structure of corporate quality management system
\end{tabular} \\
\hline $\begin{array}{l}\text { Management system. } \\
\text { Resource-saving policy }\end{array}$ & $\begin{array}{l}\text { System of product resource-intensity indicators } \\
\text { System of production resource-intensity indicators } \\
\text { Analysis of resource use effectiveness } \\
\text { Development and implementation of corporate resource-saving measures }\end{array}$ \\
\hline $\begin{array}{l}\text { Management system . } \\
\text { Methods of resource quota setting }\end{array}$ & $\begin{array}{l}\text { Types of norms and standards of corporate management } \\
\text { Methods of material resources quota setting for production } \\
\text { Methods of material resources quota setting for corporate needs } \\
\text { Methods of equipment quota setting } \\
\text { Methods of corporate labor resources quota setting } \\
\text { Methods of capital construction quota setting }\end{array}$ \\
\hline $\begin{array}{l}\text { Management system. } \\
\text { Methods of corporate technical-organizational planning }\end{array}$ & $\begin{array}{l}\text { Corporate technical-organizational indicators } \\
\text { Methods of rating of technical-organizational level of production } \\
\text { Methods of technical-organizational development prediction based on forms of } \\
\text { corporate reproduction }\end{array}$ \\
\hline $\begin{array}{l}\text { Management system. } \\
\text { Methods of corporate social development planning }\end{array}$ & $\begin{array}{l}\text { Social development indicators } \\
\text { Corporate social development planning }\end{array}$ \\
\hline $\begin{array}{l}\text { Management system. } \\
\text { Environmental protection }\end{array}$ & \begin{tabular}{|l|} 
Environmental protection legislation \\
Areas of environmental protection \\
Planning of environmental protection measures
\end{tabular} \\
\hline $\begin{array}{l}\text { Management system. } \\
\text { Corporate business plans:content and development procedure }\end{array}$ & \begin{tabular}{|l} 
Principles of corporate planning \\
Business plan development procedure \\
Business plan implementation
\end{tabular} \\
\hline
\end{tabular}




\begin{tabular}{|c|c|}
\hline $\begin{array}{l}\text { Management system. } \\
\text { Corporate processes organization }\end{array}$ & $\begin{array}{l}\text { Principles of rational production and management processes organization } \\
\text { Principle of commensurability } \\
\text { Principle of corporate differentiation } \\
\text { Forward-flow principle } \\
\text { Principle of continuity } \\
\text { Principle of uninterrupted process }\end{array}$ \\
\hline $\begin{array}{l}\text { Management system. } \\
\text { Corporate accounting and control }\end{array}$ & $\begin{array}{l}\text { Corporate accounting requirements } \\
\text { Types of control } \\
\text { Corporate control planning } \\
\text { Corporate day-to-day control automation }\end{array}$ \\
\hline $\begin{array}{l}\text { Management system. } \\
\text { Corporate motivation } \\
\end{array}$ & $\begin{array}{l}\text { Corporate motivation activities } \\
\text { Quality work motivation }\end{array}$ \\
\hline \begin{tabular}{|l} 
Managements ystem. \\
Regulation \\
\end{tabular} & \begin{tabular}{|l|} 
Factors of corporate regulation \\
Methods of feedback analysis in corporate management cycle
\end{tabular} \\
\hline $\begin{array}{l}\text { Management system. } \\
\text { Resource suport }\end{array}$ & $\begin{array}{l}\text { Types of corporate resources } \\
\text { Organization of production resource support } \\
\text { Balanced methods in organization of production resource support }\end{array}$ \\
\hline \begin{tabular}{|l|} 
Management system. \\
Methodological support \\
\end{tabular} & \begin{tabular}{|l|} 
Structure of regulatory documents in corporate management \\
Regulatory documents content requirements \\
\end{tabular} \\
\hline $\begin{array}{l}\text { Management system. } \\
\text { Dataware }\end{array}$ & $\begin{array}{l}\text { Corporate data classification and structure } \\
\text { Data requirements } \\
\text { Technology Information Support } \\
\end{array}$ \\
\hline \begin{tabular}{|l|} 
Management system. \\
Corporate legal support \\
\end{tabular} & $\begin{array}{l}\text { Corporate management legal support requirements } \\
\text { Corporate management regulations } \\
\end{array}$ \\
\hline $\begin{array}{l}\text { Management system. } \\
\text { Technical-organizational support }\end{array}$ & $\begin{array}{l}\text { Technical-organizational support requirements } \\
\text { Project technical-organizational structure for development and implementation of } \\
\text { corporate management }\end{array}$ \\
\hline $\begin{array}{l}\text { Management system. } \\
\text { Studying methods of macro factors influence on corporate } \\
\text { management stability and effectiveness }\end{array}$ & $\begin{array}{l}\text { Macro environment factors } \\
\text { Assessment studying methods of macro factors impact on corporate management } \\
\text { effectiveness } \\
\text { Assessment of macro factors impact on corporate management effectiveness }\end{array}$ \\
\hline $\begin{array}{l}\text { Management system. } \\
\text { Studying methods of regional infrastructure factors influence on } \\
\text { corporate management effectiveness }\end{array}$ & $\begin{array}{l}\text { Structure of regional infrastructure } \\
\text { Studying methods of regional infrastructure factors influence on corporate } \\
\text { management effectiveness } \\
\text { Assessment of impact of regional infrastructure factors on corporate management } \\
\text { effectiveness }\end{array}$ \\
\hline $\begin{array}{l}\text { Management system. } \\
\text { Studying methods of micro factors influence on corporate } \\
\text { management effectiveness }\end{array}$ & $\begin{array}{l}\text { Microenvironment factors } \\
\text { Studying methods of competitors } \\
\text { Studying methods ofcustomers } \\
\text { Studying methods of providers } \\
\text { Studying methods of market infrastructure } \\
\text { Assessment of corporate microstructure impact on corporate management } \\
\text { effectiveness }\end{array}$ \\
\hline $\begin{array}{l}\text { Management system. } \\
\text { Human resource management }\end{array}$ & $\begin{array}{l}\text { Principles of corporate human resource management and corporate culture } \\
\text { Corporate subdivision and job description requirements } \\
\text { Manager's business qualities assessment } \\
\text { Corporate scientific labor management }\end{array}$ \\
\hline $\begin{array}{l}\text { Management system. } \\
\text { Corporate structure of sociological and psychological factors }\end{array}$ & $\begin{array}{l}\text { Personality and staff in corporate management } \\
\text { Social aspects of corporate management } \\
\text { Corporate management style } \\
\text { Methods of reconciliation } \\
\text { Stress management }\end{array}$ \\
\hline $\begin{array}{l}\text { Management system. } \\
\text { Methods of management decisions effectiveness analysis }\end{array}$ & $\begin{array}{l}\text { Principles and methods of management decisions effectiveness analysis } \\
\text { Comparative analysis } \\
\text { Factor analysis } \\
\text { Value analysis }\end{array}$ \\
\hline $\begin{array}{l}\text { Management system. } \\
\text { Forecasting methods of } \\
\text { management decisions }\end{array}$ & $\begin{array}{l}\text { Principles and classification of predicting methods } \\
\text { Expert methods } \\
\text { Extrapolation methods } \\
\text { Parametric methods }\end{array}$ \\
\hline
\end{tabular}

The given list of standards is rather indicative. The bigger the corporation is and more technically advanced its products are, the more documentation on technical standards it must have.

All SICM must have sections "Basic issues"and "Information support". In author's opinion "Basic issues" section is supposed to show the following:

- relevance of the document (in terms of the current situation at the company); 
- reasons for developing the standard;

- purpose of the document;

- general terms and definitions;

- field of use of the document;

- authorities responsible for monitoring the implementation of the document;

- penaltyfor non-compliance with the document.

The indicative content of the section "Information support" should include:

- information requirements;

- classification of information needed for using the document;

- sources of information;

- technology and technical means for collecting, processing, transferring, filing and using information.

\section{Conclusion}

It could be inferred from all the above-mentioned that unlike traditional models of documentation the process of corporate managementhas to be built on the foundation of systematic principles defined by corporate strategy through cause-effect relation between indicators. This allows running a corporation as a system, selectively influencing only the processes and sub-systems of corporate governance that are relevant to the implementation of the overall strategy. It ensures the strategic objectives are reached through sustainable use of resources.

The authors conclude that corporate standardization should be built on a "block-based" model, where management processes are presented in the form of interrelated actions and operations which include the following: blocks of operation, communication between blocks, logic elements, databases, all of which help increase order, improve organization and develop sectoral management models in future.

\section{References}

The federal law "On technical regulation" (Art. 17).

GOST 1.1-2002 "Interstate system of standardization. Terms and definitions". Standartinform, 2003.

Tirole J. Corporate Governance // Econometrica. 2001. Vol. 69 (1). P. 1-35.

Demsetz H. Towards a Theory of Property Rights // Amer. Econ. Rev. 1967.Vol. 57. P. 350-367.

Jensen M., Meckling W Theory of the Firm: Managerial Behavior, Agency Costs, and Ownership Structure // J. of Financial Economics. 1976. Vol. 3. P. 305-360.

La Porta R., Lopez-de-Silanes F., Shleifer A., Vishny R. W. Investor Protection and Corporate Valuation // Ibid. 2002. Vol. 57(3). P. $1147-1170$.

GOST ISO 9001 - 2011 "Quality management system. Requirements" (item 4.2). Standartinform, 2012.

Frye T. Capture or Exchange? Business Lobbying in Russia // Europe-Asia Studies. 2002. Vol. 54, № 7. P. 1017-1036

Zingales L. Corporate Governance // The New Palgrave Dictionary of Economics and the Law. 1997.

Alchian A. Corporate Management and Property Rights. In: Manne H.G. (ed.). Economic Policy and Regulation of Corporate Securities. Washington, D.C.: American Enterprise Institute for Public Policy Research, 1969. P. 337-360.

Rubach M.J., Sebora T.C. Comparative Corporate Governance: Competitive Implications of an Emerging Convergence // Journal of World Business. 1998. Vol. 33, № 2. P. 167-184. 